\title{
Matrimonial Failure in George Eliot's Middlemarch: through the perspective of Social Exchange Theory
}

Naveed-ur-Rehman

Subject Specialist in English, Education Department, KPK, Pakistan

\begin{abstract}
This paper aims at to analyze the causes of matrimonial failure in George Eliot's Middlemarch among the central couples: Casaubon and Dorothea and Dr. Lydgate and Rosamond _ by applying Social Exchange Theory and its principles (rewards and costs, Comparison level, relational resources, trust and commitment and marital solidarity), through which their causes of failure of conjugal relationship are meticulously analyzed, and not fulfilling of these cause failure and fragility in central marriages in the novel.
\end{abstract}

Keywords: Casaubon, Dorothea, Lydgate, Rosamond, Matrimonial failure, Middlemarch, Social Exchange Theory

\section{Introduction}

Human relationship is one of the main themes of George Eliot's Middlemarch. In this novel, social exchange drives human relationship, particularly matrimonial relationship, in which social exchange shapes success and failure of matrimonial relationship. In the novel, three central newly marriages take place: Dorothea and Casaubon, Rosamond and Dr. Lydgate and Fred and Mary Garth. The former two marriages dominates the story in shape of exchange of rewards and costs; the latter ends the novel with the exemplary marital relationship with each other.

The motives of the protagonists' marital relationships are exclusively driven by economical and material pursuit rather than social and emotional ones; their happiness and satisfaction depend upon the fulfillment of these motives. Although married romantically in the beginning, but their romance soon fade away; for romance is the charade in order to pave way to material and social gain. Thus, their conjugal relationships are devoid of emotional attachment, mutual dependency, responsibility and care. Social exchange theory covers all such social exchange in marital relationship in the novel.

The institution of marriage has been evaluated and changed in different periods of history. In Victorian age, it got the peculiar attraction of Victorian writers, worrying about the diverse attitude about marriage. Writers like Corelli and Mona Alison Caird (1898), point out that issues regarding marriage were not resolved. According to them, marriage was the woman's divine purpose in life but reduced to business and bargaining. They argued in "The Modern Marriage

Market," that "Mothers teach their daughters to marry for a 'suitable establishment': fathers rendered desperate as to what they are to do with their sons in the increasing struggle for life ... say, 'Look out for a woman with money'" (30). But they saw affection and sacredness at a loss and romantic ideal impossible to be achieved. Such exploitation of romantic ideal can be seen in many Victorian novels, remarkably in those of Charlotte Bronte and George Eliot. 
George Eliot portrays several marriages in British community in Middlemarch. She examines prudently the lives of characters from different sections of Victorian society. She aims at to highlight common problems that happen in the novel's marriages. The novel shows the several issues related to marriage: expectation, fantasies, age-disparity, communication and status between marital partners. In this novel, views of a characters about himself and spouses set the ground for success or failure of marriage. Weiss (1984) argues that most of the marriages in this novel do not success rather fails, and this presents the irony in a period when marriage was viewed to be the solution of every problems (67). Graver (1984) opines that the reason behind the demise and decline of marriages of Lydgate and Casaubon is "the absence of any real identity of interests"(56)

It was apparent in the Victorian society that marriages was considered to be the real essence for both genders. Writers questioned the moral, social and legal foundation of marriages through different laws introduced by that time: the Matrimonial Causes Act of 1857, the Divorce Act of 1857, and the Married Women's Property Act of 1870, published serially in 1871 and 1872. Middlemarch deals with the delicate Victorian concept of marriage that evolved. She does not follow the traditional setups to end a novel with a marriage instead she discusses issues happening within a marriage.

\section{Methodology}

This is a pure qualitative attempt to analyze the matrimonial failure in the novel, Middlemarch by George Eliot. It focuses on to find out the factors behind the marital decline for which the sociological perspective has been chosen: Social Exchange Theory. This is an innovative approach towards marital relationship as it aims at social exchanges within marital relationship. Besides, it explain the development, maintenance and decay depending on the exchange process within a relationship. Middlemarch deals with such exchange process in marital relationships which defines couples' success or failure.

\section{Theoretical Framework}

Theoretical framework to analyze the decline and fall in the marital relationship in the marriages in the novel Middlemarch by George Eliot is Social Exchange Theory by Homman and Thibuat and Killy. It closely examines the factors responsible for marital failure and fragility between dyadic relationships. The researcher chooses this Theory as the fit, robust and viable framework that tells us how a person enters into relationship with the hope of maximizing happiness, achieving goals and identifying the status expected and minimizing costs that is time, energy and effort.

\section{Social Exchange Theory (SET)}

Canary \& Zelley (2000) advocates that Social exchange theory is a robust explanatory rationale for relationship maintenance. Developed by Thibaut and Kelley (1959), social exchange theory contends that individuals make different assessments about relationship satisfaction and make different decisions about relationship commitment based on two values: rewards and costs. Social exchange theory evaluates relationships based on a relatively rational approach. The theory examines the interplay and balance between the rewards an individual receives from a certain relationship and the costs that he or she expends in that relationship. 
The Social Exchange Theory by Thibaut and Kelly (1978) emerged from economy, sociology and psychology. It was originally pioneered by George Human in 1959. Sociologists like Blau, Thibaut and Kelly, and Emerson contributed to the greater extent in developing it. The social exchange theory assumes that all human relationships that take place based on costs and rewards and people evaluate and seek to increase the rewards and reduce the costs and take a rational decision of whether or not to enter into a relationship. Costs, the negative factors, affects exchange behaviors within a marriage, rewards are the pleasures, satisfactions, and gratifications that a person enjoys within a marriage (Thibaut \& Kelley, 1959). Social Exchange Theory explains that human beings inters into a relationship when they have the expectation of bringing any goodness and positive outcome (Blau, 1964; Thibaut \& Kelly, 1959).

Social exchange theory is a useful and practical perspective to study social exchange processes in matrimonial relationships. It seeks to explain the development, maintenance, and decay of exchange relationships on the basis of fair distribution of the rewards that marital partners obtain and the costs that they incur.

\section{Discussion}

Looking at the way how couples like Casaubon and Dorothea and Lydgate and Rosamond develop their relationships before their marriages, it may be observed that every one of them want to a have a partner with whom they could start their lives and bless their lives with as much rewards as possible. Both couples do justice to each other by exchanging maximum rewards - cost in order to build net profit that is marriage. Indeed, they build a solid foundation for their marital relationship by exchanging care, feeling, love, attraction and tenderness. Both the parties choose one, who, according to them, could maximize their rewards and curtail costs. By maximizing rewards mean that their status, identity, decision, influence and equality be accepted. It may be wonderful to see that one partner wants to provide with much rewards and decrease the costs if any and the other party do not try to understand to reciprocate the same, and this leads to complexities and conflict in their lives. For example, in the martial relationship between Casaubon and Dorothea, it is the Casaubon who does not exchange the rewards and costs with his wife, Dorothea in the same quantity Dorothea exchanges with him. Similarly, it is Rosamond who creates conflicts, depression and dissatisfaction for Lydgate by increasing cost and disappearing the rewards.

If we conclude the pre-marital stages, both marital partner display the equal distribution of rewards and costs and have high level of comparison. Although, Dorothea selects Casaubon by refusing James as she sees him the comparison level of alternative as Casaubon could be the sources of joy, happiness, satisfaction and care more that James could be. Here, she misjudges James and takes Casaubon as the future husband. Similarly, Lydgate and Rosamond share the fair distribution of rewards and costs in early stages- courtship. So, both couples' net product and outcome is marriage, which actually takes place.

In Middlemarch, marital partners like Casaubon and Dorothea and Lydgate and Rosamond and their motives are self-centered and individual. These motives are not made to maximize the other partner's life instead they think that their own life should be full of such rewards. Casaubon's 
motives, according to SET, his rewards he expects from Dorothea are that she will act like house wife and provides with satisfaction and happiness like a typical wife and a wife who will not dominate him and never challenge him in any matter. On the other hand, Dorothea dreams about an ideal life with the scholar, Casaubon, whom she considers a wonderful man and "very dignified ... the portrait of Lock...the most interesting man... a man like him providing knowledge ...bring her up intellectually and direct her

Professionally...though only as a lamp holder" (Eliot14). She imagines Casaubon a person, "who was in all respects superior to her ... the most distinguished-looking man" (18). Moreover, she expects form him that he will raise her status by giving her an opportunity help him in book and research.

Lydgate and Rosamond equally join Casaubon and Dorothea in matter of maximizing rewards. In this marital relationship, Rosamond seems to be materialistic and worldly as she expect Lydgate will provide her with sound life far apart from those living in Middlemarch. She also expects form him that he may uplift her status and get rid of Middlemarch society she despises too much. In complete contrast Lydgate paints her a suitable and ideal wife for his life and sees in her the charm and compassionate nature he dreams form many years, say that "“s [s] he is grace itself; she is perfectly lovely and accomplished. That is what a woman ought to be; she ought to produce the effect of exquisite music" (Eliot 93). He expects form Rosamond that she will make him happy, support and give him an identity in Middlemarch society.

This portion of the paper focuses on the continuity and decay of marital relationship through the perspective of Special Exchange Theory. The novel mostly deals with marital problems and conflicts. After the period of golden day of marriage, both couples witness challenging circumstances which exposes their real nature and approach towards marriage and marital partner. Both see the drastic decrease in rewards they expected from partners. The fluctuation in the rising and lowering rewards and costs in their marital relationship leads to constant tension and conflict which they fail to resolve. The loss of rewards and increase in costs are not at once but in sequence such as one action leads to reaction or another action. We can say that one act is responsible for another action which happens always negatively. Their frustration, depression and lack of dependence on each other are due to the domination of cost which they provides with, and forgets to understand others' rewards.

Casaubon mainly plays the role of destroying the rewards and causing much costs to Dorothea. He does not know what Dorothea expects from him. His social behavior, manner, and communication as a husband do not maximize Dorothea's rewards rather it increases her costs to alarming stage. Every new change, revelation in his character depress and disturb her.

Marital relationship between Casaubon and Dorothea consists of social exchange in which costs outweigh rewards to the great extent. The net profit of their relationship suffers due to the unfair distribution of rewards and costs. Marital partners with favorable rewards/ costs outcome and balanced distribution of rewards and costs are satisfied with their marriage (Homans, 1974). (Levinger, 1979) opines that there is no chance of separation or failure of marriage if marital partners are satisfied with marriage. In contrast, if they do not get favorable rewards, they are not 
satisfied with their marriage. When rewards in marital relationship disappear, and a fair and loving behavior are not rewarded, the relationship goes on decline stage and does not stand as stable one.

Dorothea frequently attempts to maintain this relationship on the cost of her dreams and motives; she wants to maintain the marital solidarity by obeying and complying Casaubon's decision, priorities and wishes as she feels dependent on the marital relationship and she does not want to exit it. But we evaluate the exchange from Casaubon's side, it seems clear that he has stopped depending on the marital relationship with Dorothea as he does not listen to her feeling, words and inside conflict; he is not in the position to respect her priorities and decision. By doing so he not only makes his life miserable but also of the Dorothea; she is often found in "self-accusing cry" (Middlemarch, 218) and "the feeling of desolation" (Middlemarch, 218). Her life is so tensed and depressed that "Dorothea found herself plunged in tumultuous preoccupation with her present lot" (Middlemarch, 219) and starts repenting of marrying him due to much costs and less rewards.

A partner evaluates his or her relationship in a marriage on the basis of costs and rewards and value a relationships when it is above a comparison level, which may give him marital solidarity. Comparison level is a standard representing what people feel they should receive in the way of rewards and costs from a particular relationships (Thuabaut and Kelly 1978); it is the lower level of rewards acceptable for the person. Though it, an individual evaluate relationships. It may be determined by assessing all the known costs and rewards incurred with the relationship based on previous experience.

When Dorothea evaluates her marital relationship with Casaubon, she feels that does not get what she expected form him and compare her present life with the past she feels dejection and depression and "a certain terror ... inward fits of anger and repulsion ... forlorn weariness" (Middlemarch, 223)as level of comparison get lowered and declined. Although comparison level is on lower stage, she decide to continue this negative relationship on the sacrifice of her rewards. According to SET, when a comparison level is not high, a person either continues the relationship or terminates the relationship.

Comparison level for alternative is considered to be the lowest level of rewards a person accepts from alternative sources. It happens when the existing relationship does not provide the expected rewards, he or she is likely to accept this abused kind of relationship or look for another person as alternative to get the expected rewards with minimum costs. In this case, a person may terminates his or her relationship with the partner or continue it (Thibaut \& Kelley, 1959). It is a fact Dorothea has comparison level for alternative in shape of Will Ladislaw as she find him more loving, caring and responsible but she chooses Casaubon again in order to give Marital solidarity to their relationship. She actually curtails the chances of alternative by depending on the relationship.

Level of outcome that is rewards minus cost or favorable rewards is relative to comparison level, it defines a partner's high level of attraction to marital relationship. If the level of outcomes is relative to the comparison level, it defines a partner's attraction to the marital relationship, and inversely, if the outcome gets lower to the comparison level, it means that the level of attraction to the marital relationship has declined to the alarming stage (Thibaut \& 
Kelley, 1959). Here, Casaubon's outcome is not relative to comparison level it means that he loses his attraction to the marital relationship to the alarming stage. Similarly. Dorothea loses attraction to the relationship as her outcomes are terribly and drastically disturbed and disappointed.

Bothe Casaubon and Dorothea's outcomes are not above to their level of comparison, the marital solidarity is lost. Marital solidarity depends on outcomes above their level of comparison and high level of attraction. They do not try to exchange rewards favorably so that comparison level could maintain relative or above and bring more attraction to their marital relationship. Both live in their own world instead of communicating each other's trouble and internal conflicts.

Lydgate and Rosamond presents another but opposite picture of social exchange in their marital relationship. Here, we witness a crucial blow to the social exchange between them as Rosamond-female character- wife of Lydgate, does not support, help and stand by her husband in times of tribulations, which are the principles (support, help and approval) of rewards one expects form marital partner in situation whatever. When Lydgate becomes economically frustrated due to much debt, Rosamond becomes so cynical and critical that Lydgate is emotionally broken and hurt. There is a reason behind Rosamond' harsh and selfish behavior that is she see her motives (rewards) exploited and lost, and she also imagines her dark and unstable life in future (costs). She says to him that "[d]o you know, Tertius, I often wish you had not been

a medical man" (Middlemarch522). Such remarks from a Rosamond is not expected but, he answers tenderly "[n]o, Rosy, don't say that, this is like saying that you wished you had married another man" (Middlemarch522). So, here too costs outweigh rewards that is rewards are not equal to costs. That is why their relationship suffers to the great extent. According to SET, if rewards and cost are on equitable stage, marital relationship is likely to continue and if not the marital relationship is like to decline and may be unstable.

The decline and instability in the marital relationship between Lydgate and Rosamond occur due to the low level of comparison. Both expected care, support and love from each other. Their marital relationship suffers as both feels that they did not get rewards as expected instead it maximized their costs. When they evaluate their marital relationship on the basis of costs and rewards, for both their costs surpasses rewards; rewards are not equal to costs. It mean both do not get favorable rewards from this relationship, that's why comparison level is disturbed. The fact is that Lydgate continues supporting, helping her in the fulfillment of her motives as he "loved her as tenderly as ever" (Middlemarch671)., but her obstinate and selfish behavior do not let him to continue the same action as there are no rewards for it instead it only maximizes his costs. Both continue the same relationship as there is no comparison level of alternative.

A relationship may get instable if there is one partner's low level of dependence on the marital relationship (Kurdek, 1993). It means that greater stability within marital relationship depends on both partners' high level of dependence. Marital partner may experience distress and disappointment in case of variance in their level of interdependence due to the lack of commitment to the marital relationship. Commitment is defined as "the degree to which the self is identified with the marital relationship" (Edwards \& Saunders, 1981, p. 384). Marital trust helps in building 
strong marital commitment and so the marital commitment, which may assure marital solidarity by increasing the mutual bond and curbing the comparison level of alternative (McDonald, 1981).

The level of dependence of both Casaubon and Dorothea on marital relationship is not up to the satisfaction, that's why marital stability is disturbed and seems almost lost between them. Casaubon lives in his frustration and disappointment; he does not show any interest in Dorothea's happiness, concerns and goals. He does not steps forward to protect the relationship by lowering his expectations and manhood. This relationship seems to be a burden on his shoulder due to his own attitude; he is jealous of Will Ladislaw's closeness towards Dorothea and also suspect Dorothea's character of being involved in Ladislaw His suspect on Dorothea is so strong that no explanation could remove his suspect; he thinks that Dorothea, who ha[s] worshipped him ... turned into the critical wife" Casaubon misjudge "Dorothea's silence ... a suppressed rebellion" (Middlemarch, 477).. Dorothea, on the other side. Keeps on thinking how to realize him the love, feeling and inclination of her. Her dependency is greater than that of Casaubon. It shows her everlasting and unending commitment and trust, which does not belong to Casaubon. Casaubon's low level of dependency shows that he is not committed to this sacred bond and does not keep the trust on Dorothea. Dorothea increases her mutual bond and curtail the comparison level of alternative for marital stability but Casaubon's attitude leads her to alarming level of frustration and depression.

Similarly, Rosamond and Lydgate's level of dependence on marital relationship miserably suffer due to the Rosamond's low level of dependence. Rosamond is not satisfied with the way Lydgate provides with facilities, materialistic needs and emotional satisfaction. She feels that her life has entered into the dark stage by Lydgate's adamant and flat decisions and his being not flexible to win the circumstances. When her needs and motives are not met according to her expectation, her level of dependence on marital relationship drastically gets down. Although, Lydgate attempts to persuade her that such crucial and difficult stage of life will soon be over, and he also advises her to be patient and keeps trust on him. But Rosamond turns deaf ear to her words and emotions too. So, their marital stability becomes lower and lower due to the low level of dependence. It shows Rosamond's lack of trust and commitment to the bond. The loss of trust and commitment leads to drastic consequences which often lead to separation and "there was gathering within him an amazed sense of his powerlessness over Rosamond" (Middlemarch, p. 671). Although, they do not get separated but live a life of no interest and romance.

Level of outcomes for both Lydgate and Rosamond are not relative or above to their comparison level, it defines their low level of attraction to marital relationship. Lydgate, although, tries to maintain his level of attraction not caring about the outcomes, but at last he loses his attraction to the marital relationship due to the cold and carless behavior of Rosamond. So is the case with Rosamond. She lose attraction to the level that she forget about her outcomes and about her motives. They do not keep the marital solidarity in their relationship by keeping low level of attraction and outcome not above their comparison level. Marital solidarity could only be maintained by keeping high level of attraction to the marital relationship and outcomes above comparison level. 
Social exchange within marital relationship may be affected by the transaction of resources positively or negatively relative to the capability of a partner. Emerson (1976) defined a resource in a social exchange as "an ability, possession, or other attribute of an actor [partner] giving him [or her] the capacity to reward or punish another specified actor [partner]" (p. 347). The transaction of rewards and costs that partners transfer to each other is considered as one of the central roles of social exchange.

There are two kind of resources marital partners administer within marital relationship:

Positive and coercive power. If one partner's reward enables him to cause positive event or assist another partner in achieving his goals or dreams, such resource is supposed to be called positive power. Contrastingly, if one partner's ability to administer costs or punishment for another partner or causes negative event or environment to impede him in achieving goals or motives, such negative power is called coercive power(Kelley, 1983).

Casaubon comes up with the use of resource that is coercive power to impede the goals or expectation held by Dorothea. Firstly, he creates unending jealousy and suspect in his actions and words which kills Dorothea romantically and emotionally. Secondly, He writes a codicil for not marrying Will Ladislaw in case he dies. So, he uses coercive power by creating negative circumstances for her. On the other hand, Dorothea decides to maintain the relationship with Casaubon after enduring the indifferent attitude of Casaubon; she forget every wounds, bad attitude and harsh treatment. In this way she creates a way to continue the relationship.

Similarly, Rosamond's indifferent, uncaring and hurting attitude towards Lydgate creates a distance between them. She uses coercive power in shape of impatience, harsh attitude and passive listening to Lydgate. Similarly, Lydgate's proud behavior hurts her; he does not listen to her words and ignores her decisions and does not take her help. By using such power, both create negative circumstance for the hopes and expectations they have from each other.

Such resource differential leads to asymmetry in their marital relationship, which brings rise of exploitation in marriage. Resource differential, thus, produces relationship asymmetry. The asymmetrical nature of the relationship allows for the emergence of exploitation in the marital relationship (Blau, 1964). Such situations produces imbalance in marital partners. They do not care of rewards and costs. Casaubon exploit the dreams and motives of Dorothea and, so does Rosamond, who exploits the leading dreams of Lydgate. By doing so, romance, care, love and responsibility lose their meaning and usefulness. Couples live a dissatisfied and depressed lives.

\section{Conclusion}

Marital relationships in the novel, Middlemarch become dysfunctional due to the weak social exchanges of rewards- love, care, trust and commitment and strong exchange of costs- distance, lack of communication, distrust, hatred, anger and lack of commitment, leading to conflicts and problem. Such negative exchange of behaviors surpass their good and rewarding behaviors. The unexpected circumstances, negative treatment, and harsh attitude of one partner towards other partner spoil the caring and loving environment in marital relationship. In this way, interpersonal exchange within the marriage may become fragile; the interdependency, mutual involvement and identification may weaken; liking and attraction may fade away; the level of compatibility may 
less share; solidarity may come on the losing point and it may lead to the disappearance of love and affection. The everlasting happiness in marital relationship could only be achieved if partners provide with rewards expected from each other and try to remove all the costs come in their way.

\section{References}

Blau, P. M. (1964). Exchange and Power in social life. New York: John Wiley.

Chavannes, A. (1901). Studies in sociology (2nd ed.). Knoxville, TN: New Thought Library Corelli, Marie. (1898)."The Modern Marriage Market." London,. Victorian Women

Edwards, J. N., \& Saunders, J. M. (1981). Coming apart: A model of the marital dissolution decision. Journal of Marriage and the Family, 43, 379-389.

Emerson, R. M. (1976). Social exchange theory. In A. Inkeles, J. Coleman, \& N. Smelser (Eds.), Annual Review of Sociology (vol. 2, pp. 335-362). Palo Alto, CA: Annual Reviews.

Graver, Suzanne. "Mill, Middlemarch, and Marriage." Portraits of Marriage in Novel." Portraits of Marriage in

Literature . Illinois: Western Illinois UP, 1984.

Homans, G. C. (1974). Social behavior: Its elementary forms (rev. ed.). New York: Harcourt Brace Jovanovich.

Kelley, H. H. (1983). Close relationships. New York: W. H. Freeman and Company

Kurdek, L. A. (1993). Predicting marital dissolution: A 5-year prospective longitudinal study of newlywed couples. Journal of Personality and Social Psychology, 64, 221-242

Levinger, G. (1979). Marital cohesiveness at the brink: The fate of applications for divorce. In G. Levinger and O. C. Moles (Eds.), Divorce and separation (pp. 137-150). New York: Basic Books. Literature . Illinois: Western Illinois UP, 1984. 55-66

McDonald, G. W. (1981). Structural exchange and marital interaction. Journal of Marriage and the Family, 43, 825-838.

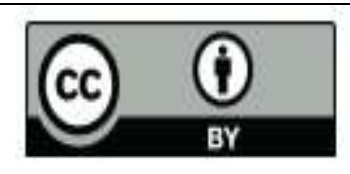

@ 2017 by the author. Licensee University of Chitral, Journal of Linguistics \& Literature, Pakistan. This article is an open access article distributed under the terms and conditions of the Creative Commons Attribution (CC BY) (http://creativecommons.org/licenses/by/4.0/). 